\title{
Chemistry of Cyclopentadienyliron Dicarbonyl Dimer and Ferrocene in Zeolite $Y$ Cavities: Anchoring Organometallic Fragments into Microporous Solids
}

\author{
Karin Moller, Aticha Borvornwattananont, and Thomas Bein* \\ Department of Chemistry, University of New Mexico, Albuquerque, New Mexico 87/31 \\ (Received: August 31, 1988; In Final Form: December 20, 1988)
}

\begin{abstract}
The intracavity chemistry of $\left[\mathrm{CpFe}(\mathrm{CO})_{2}\right]_{2}(1)$ and ferrocene in different acid forms of zeolite $\mathrm{Y}$ has been studied with EXAFS, in situ FTIR, and TPD-MS spectroscopies. Depending on the stoichiometry of zeolite protons vs the amount of starting complex 1 , the complex is either oxidatively cleaved into $\mathrm{CpFe}(\mathrm{CO})_{3}{ }^{+}(2)$ and $\mathrm{CpFe}^{+}$coordinated to the zeolite, or protonated to form dimeric $\left[\mathrm{CpFe}(\mathrm{CO})_{2}\right]_{2} \mathrm{H}^{+}(3)$. It is shown that the stability of all complexes is influenced by the intracavity concentration of the zeolite-bridged hydroxyl groups. The cationic monomer 2 is stable up to $500 \mathrm{~K}$ in the highly acidic zeolite host, whereas the protonated dimer decomposes above $400 \mathrm{~K}$. At higher temperatures, all carbonyl ligands are split off from the iron complexes, and the remaining dominant fragments are identified as $\mathrm{CpFe}(\mathrm{OZ})_{n}(n=2-3)$, bonded to the zeolite host structure via oxygen coordination. Similar fragments are formed upon thermal decomposition of ferrocene in the zeolite.
\end{abstract}

\section{Introduction}

The immobilization of catalytically active species derived from organometallic catalysts is motivated by the potential combination of several benefits, including better separation from reaction products, site isolation, and higher stability compared to the parent compounds. A wide range of transition-metal $\pi$-allyl, Cp (cyclopentadienyl), and olefin-derived catalyst precursors have been prepared during the last decade, including group IV, VI, and VIII metal species supported on amorphous oxides. ${ }^{1-4}$ However, the scope of support/host systems can in principle be significantly extended to include the well-defined, crystalline pore structures of zeolites. Zeolites are porous metal oxides, typically aluminosilicates, which offer channel structures with pore diameters in the $3-12-\AA$ range with ion-exchange capability and adjustable electronic/acidic properties. ${ }^{5-7}$ Zeolites are particularly attractive supports for several reasons: In addition to the expected benefits of conventional hybrid catalysts, the zeolite cage system may play an active catalytic role by imposing high diffusional selectivity, altered stereochemistry, and stabilization of unusual structures. As a result of previous attempts to immobilize catalysts in zeolites, it became apparent that low-valent metal species such as carbonyls or small metallic clusters show only weak interaction with the zeolite surface. ${ }^{8.9}$ The resulting agglomeration of the metal phase and potential migration to the host surface reduces the unique selectivity induced by the zeolite pore structure. ${ }^{10}$

We explore routes to immobilize organometallic fragments via formation of stable bonds between the metal species and the highly reactive inner surface of the acid form of zeolites. This concept has been demonstrated by utilizing an HY zeolite host to entrap triallylrhodium." Zeolites offer the possibility of controlled reactant-support interaction with their well-characterized adsorption sites. An additional benefit of this immobilization strategy is the great extent of control over the intrazeolite location of the metallic fragments: Large ligands such as $\mathrm{Cp}$ and gentle reaction conditions can prevent diffusion of the fragments into smaller cages which would not be accessible to some reactant molecules. In contrast, the classical route to, e.g., intrazeolite $\mathrm{Rh}$ carbonyls involves metal ion exchange and severe dehydration steps at high

(1) Yermakov, Y I Catal. Rev,-Sci. Eng. 1976, /3,77,

(2) Ward. M. D.: Schwartz, J. J. Mol. Catal. 1981, M, 397.

(3) Spek, T. G.; Scholten, J. F. J. Mol. Catal. 1977, 3,81.

(4) Foley. H. C.; DeCanio, S. J.: Tau, K. D.; Chao, K. J.; Onuferko, J. H.;

Dybowsky, C. Gates, B. C. J. Am. Chem Soc. 1983, 105, 3074

(5) Jacobs, P. A.; Mortier, W. J.; Uytterhoeven, J. B. J. Inorg. Nucl. Chem. 1978, 40,1919

(6) Bein, T.: Jacobs, P. A. J. Chem. Soc., Faraday Trans. I 1983, 79, 1819; 1984. 80.1391

(7) Breck, D. W. Zeolite Molecular Sieves; Krieger: Malabar, FL, 1984

(8) Bein, T.; Schmiester, G.; Jacobs, P. A. J. Phys. Chem. 1986, 90, 4851

(9) Bein. T: McLain, S. J.: Corbin, D. R.; Farlee, R. F.; Moller, K. Stucky (j. D. Woolery, G.: Savers, D. J. Am. Chem. Soc. 1988, 110,1801 (1) Davis M. E.: Rode. E: Taylor. D.: Hansen, B. E. J. Catal. 1984, 86

1]1) Huane. T. V.: Schwartz, J. J. Am Chem. Soc 1982, 104, 5244 temperature which cause cation migration into smaller cages. Hence, subsequent coordination chemistry can include or even be limited to metal ions located in less accessible small cages.

Large pore zeolite $\mathrm{Y}$ (faujasite) has been chosen as the host structure in the present study. Three types of cages with different sizes are generated in zeolite $\mathrm{Y}$ by interconnected corner-sharing $\mathrm{AlO}_{4}$ or $\mathrm{SiO}_{4}$ tetrahedra: the small double six-ring with a free pore diameter of $2.6 \AA$, the larger sodalite unit (diameter $6.6 \AA$ ), accessible through single six-rings, and the supercage with 12 -ring windows of approximate $7.5 \AA$ and a diameter of $12.5 \AA$. Internal diffusion is possible through the three-dimensional network of the supercages or through the smaller six-ring windows of the sodalite cages. The negative charge of the framework is compensated by cations, which, after dehydration, occupy defined positions in the crystal structure. The cations can be exchanged by other cations or by protons to form acidic supports with adjustable hydroxyl concentration. Intra-faujasite hydroxyls are based on bridged oxo units in contrast to the terminal hydroxyls found on amorphous metal oxide surfaces.

A fundamental understanding of relative ligand stabilities in the zeolite pore system is required for a rational design of zeolite-based transition-metal hybrid catalysts. We explore the reactivities of a number of representative ligands of iron complexes with respect to the intrazeolite hydroxyl groups. In this study, the intrazeolite chemistry of $\left[\mathrm{CpFe}(\mathrm{CO})_{2}\right]_{2}(\mathrm{Cp}=\eta-5$-cyclopentadienyl) (1) and ferrocene in zeolite $\mathrm{Y}$ has been examined with EXAFS, FTIR, and TPD-MS spectroscopies. It is found that at elevated temperatures all carbonyl ligands are split off from the intermediate products to form the "half-sandwich" $\mathrm{CpFe}^{+}$. $(\mathrm{OZ})_{n}{ }^{-}(4)$, which is coordinated to 4- and 6-membered rings in the zeolite supercage. A similar intrazeolite fragment (4) is obtained from ferrocene when heated in the acid zeolite under vacuum

\section{Experimental Section}

Sample Preparation. Three different supports were used in this study: NaY (commercial Linde LZ-Y 52 $\left[\mathrm{Na}_{57} \mathrm{Al}_{57} \mathrm{Si}_{135} \mathrm{O}_{384}\right] \cdot 235 \mathrm{H}_{2} \mathrm{O}$ ), partially proton exchanged $\mathrm{H} 2 \mathrm{Y}$ derived from LZ-Y52 via ion exchange with $2 \mathrm{NH}_{4}{ }^{+}$per supercage (in $\mathrm{NH}_{4} \mathrm{Cl}$ solution under reflux for $24 \mathrm{~h}$ followed by several washings) to give support $\mathrm{H} 2 \mathrm{Y}$, and highly acidic $\mathrm{H} 6 \mathrm{Y}\left(6 \mathrm{H}^{+} / \mathrm{sc}\right.$, $s c=$ supercage $)$ derived from Linde LZ-Y62 $\left[\left(\mathrm{NH}_{4}\right)_{45} \mathrm{Na}_{10^{-}}\right.$ $\mathrm{Al}_{55} \mathrm{Si}_{137} \mathrm{O}_{384} \cdot 235 \mathrm{H}_{2} \mathrm{O}$. Heating under vacuum at $1 \mathrm{~K} / \mathrm{min}$ up to $700 \mathrm{~K}$ gave the desired acid form of the zeolite. The degassed zeolites were transferred into a glovebox for further treatments. Sample notations indicate the formal amount of protons per supercage to allow comparison with the amount of molecules adsorbed into the support. The unit cell (uc) in faujasites contains eight supercages. It should be noted that the protons are dis. tributed between the supercages and the sodalite cages. Based upon previous work, the protons are partitioned approximately $1: 1$ in these two cage systems. ${ }^{12}$ Loading with commercial 
TABLE I

\begin{tabular}{lllc}
\hline sample name & \multicolumn{1}{c}{ support } & iron species & concentration \\
\hline NaYFp2 & $\mathrm{NaY}$ & {$\left[\mathrm{CpFe}(\mathrm{CO})_{2}\right]_{2}$} & $0.5 / \mathrm{sc}$ \\
$\mathrm{H} 2 \mathrm{YFp} 2$ & $\mathrm{HY}\left(2 \mathrm{H}^{+} / \mathrm{sc}\right)$ & {$\left[\mathrm{CpFe}(\mathrm{CO})_{2}\right]_{2}$} & $0.5 / \mathrm{sc}$ \\
$\mathrm{H} 6 \mathrm{YFp} 2$ & $\mathrm{HY}\left(6 \mathrm{H}^{+} / \mathrm{sc}\right)$ & {$\left[\mathrm{CpFe}(\mathrm{CO})_{2}\right]_{2}$} & $0.5 / \mathrm{sc}$ \\
$\mathrm{H} 2 \mathrm{YFeCp} 2$ & $\mathrm{HY}\left(2 \mathrm{H}^{+} / \mathrm{sc}\right)$ & $\mathrm{FeCp} 2$ & $2.0 / \mathrm{sc}$ \\
$\mathrm{FeY}$ & $\mathrm{NaY}$ & $\mathrm{Fe}(\mathrm{II})$ & $9.0 / \mathrm{uc}$
\end{tabular}

$\left[\mathrm{CpFe}(\mathrm{CO})_{2}\right]_{2}(1)$ and ferrocene (both Aldrich) was accomplished by stirring a slurry of $0.500 \mathrm{~g}$ of zeolite with the required amounts of organometallic compound in $50 \mathrm{~mL}$ of hexane for $12 \mathrm{~h}$ under nitrogen. The uptake into the zeolite could be followed by decoloration of the hexane and was typically completed after 4-8 $h$. The solvent was partially removed by brief evacuation on a frit. Reactions in $\mathrm{H} 2 \mathrm{Y}$ were found to be similar to those in ultrastable, decationized zeolite Linde LZ-Y72. The zeolites were loaded with ca. 0.5 molecules of complex 1 per supercage and with 2 molecules ferrocene per supercage. For comparative EXAFS studies, $\mathrm{NaY}$ zeolite was exchanged with $\mathrm{Fe}$ (II) ions via anaerobic ion exchange with $\mathrm{FeSO}_{4}$ to yield $\mathrm{Fe}_{9} \mathrm{Na}_{39}\left(\mathrm{AlO}_{2}\right)_{57}\left(\mathrm{SiO}_{2}\right)_{135}$ (Galbraith Laboratory). The filtered and dried sample was heated at $2 \mathrm{~K} / \mathrm{min}$ to $623 \mathrm{~K}$ under oxygen flow, evacuated, and cooled to room temperature, and heated under hydrogen flow to $623 \mathrm{~K}$. Sample characteristics and names are compiled in Table I.

During in situ FTIR-MS measurements (see below), samples were heated either at a rate of ca. $1 \mathrm{~K} / \mathrm{min}$ to $460 \mathrm{~K}$ (actual sample temperature measured at the Si support wafer), or by a step function at $1 \mathrm{~K} / \mathrm{min}$ to $333 \mathrm{~K}$, kept at this temperature for $10 \mathrm{~h}$, and subsequently heated with the same rate to $383 \mathrm{~K}$, kept for $10 \mathrm{~h}$, and finally heated to $500 \mathrm{~K}$. Heat treatments of the above samples for the EXAFS measurements were done in small quartz reactors connected to a vacuum line with $10^{-5}$ Torr base pressure. A $0.5-\mathrm{g}$ portion of the sample was heated at $1 \mathrm{~K} / \mathrm{min}$ to $373 \mathrm{~K}$, kept at this temperature for $10 \mathrm{~h}$, and subsequently heated at $1 \mathrm{~K} / \mathrm{min}$ to $473 \mathrm{~K}$ and kept for $10 \mathrm{~h}$. Samples were recovered after each $10-\mathrm{h}$ period. When appropriate, the treatment temperature is added to the sample name.

FTIR-TPD-MS. FTIR data were obtained with a Mattson Polaris spectrometer at $4-\mathrm{cm}^{-1}$ resolution. Thin dispersions of the zeolite samples were deposited on IR-transparent Si wafers and introduced into a heatable in situ cell under nitrogen atmosphere in a glovebox. The cell was coupled to an ultrahigh vacuum thermodesorption apparatus combined with a quadrupole mass spectrometer (Dycor M200, 1-200 amu). A base pressure of $10^{-10}$ Torr was achieved with a cryogenic pump. Samples were evacuated until the pressure dropped below $10^{-7}$ Torr at room temperature prior to each experiment. Up to five mass fragments could be monitored as a function of time/temperature in the TPD/MS experiments. Additional TPD/MS data were obtained on a Finnigan mass spectrometer by scanning masses $20-1000$ while heating from 323 to $623 \mathrm{~K}$ at a heating rate of $16 \mathrm{~K} / \mathrm{min}$.

EXAFS. EXAFS measurements were performed at NSLS Brookhaven National Laboratory at beamline X-11A with a stored electron energy of $2.5 \mathrm{GeV}$ and ring currents between $60-110 \mathrm{~mA}$. Fe K-edge data at $7112 \mathrm{eV}$ were collected at about $100 \mathrm{~K}$ in transmission by using a $\mathrm{Si}(111)$ monochromator. The powdered samples were sealed in a 1:1 dodecane/octadecane mixture and kept under nitrogen until EXAFS data were collected. The sample thickness was adjusted such that the total absorption did not exceed $\mu x=2$ to provide an optimum signal-to-noise ratio.

The EXAFS data were analyzed following standard procedures. ${ }^{13}$ Phase shifts and backscattering amplitudes were extracted from the following references (scatter shells in parentheses): $\mathrm{Fe}$ foil $(\mathrm{Fe}-\mathrm{Fe}), \mathrm{Fe}(\mathrm{III})$ acac $(\mathrm{Fe}-\mathrm{O})$, ferrocene $(\mathrm{Fe}-\mathrm{C})$, and $\mathrm{FeC}_{3} \mathrm{H}_{5}(\mathrm{CO})_{3} \mathrm{Cl}(\mathrm{Fe}-\mathrm{CQ})$. Crystallographic data of the reference compounds and Fourier transform ranges used in the data analysis are listed in Table II. K-edge background removal was accomplished by subtracting a Victoreen curve and fitting with a cubic

(12) Gallezot, P.; Imelik, B. C. R. Acad. Sci. Paris, Ser, B 1970, 27I, 912 (13) Lee, P. A.; Citrin, P. H.; Eisenberger, P.; Kincaid, B. M. Rev. Mod. Phys. 1981, 53, 769 .
TABLE II: Fourier Transform Ranges, Interatomic Distances $\boldsymbol{R}$, and Coordination Numbers $\boldsymbol{N}$ of Reference Compounds

\begin{tabular}{|c|c|c|c|c|c|c|}
\hline $\begin{array}{l}\text { reference } \\
\text { compd }\end{array}$ & scatterer & $K / \AA^{-1 a}$ & $R / \AA^{b}$ & $R / \AA$ & $N$ & ref \\
\hline $\mathrm{Fe}$ foil & $\mathrm{Fe}-\mathrm{Fe}$ & $2.8-16.0$ & $1.3-3.0^{c}$ & 2.482 & 8 & 29 \\
\hline $\mathrm{Fe}(\mathrm{III}) \mathrm{acac}$ & $\mathrm{Fe}-$ & $2.8-16.1$ & $1.2-2.3$ & 1.992 & 6 & 30 \\
\hline & & $3.0-16.0$ & $1.1-2.3$ & 2.033 & 10 & 31 \\
\hline $\mathrm{FeC}_{3} \mathrm{H}_{5}(\mathrm{CO})_{3} \mathrm{Cl}$ & $\mathrm{Fe}-\mathrm{CO}$ & $3.2-15.8$ & $2.2-3.2$ & 2.928 & 3 & 32 \\
\hline
\end{tabular}

${ }^{a}$ Fourier transform range applied to reference data. ${ }^{b}$ Inverse Fourier transform range applied to reference data. ${ }^{C}$ Range includes shell at $R=2.866(N=6)$ which cannot be separated.

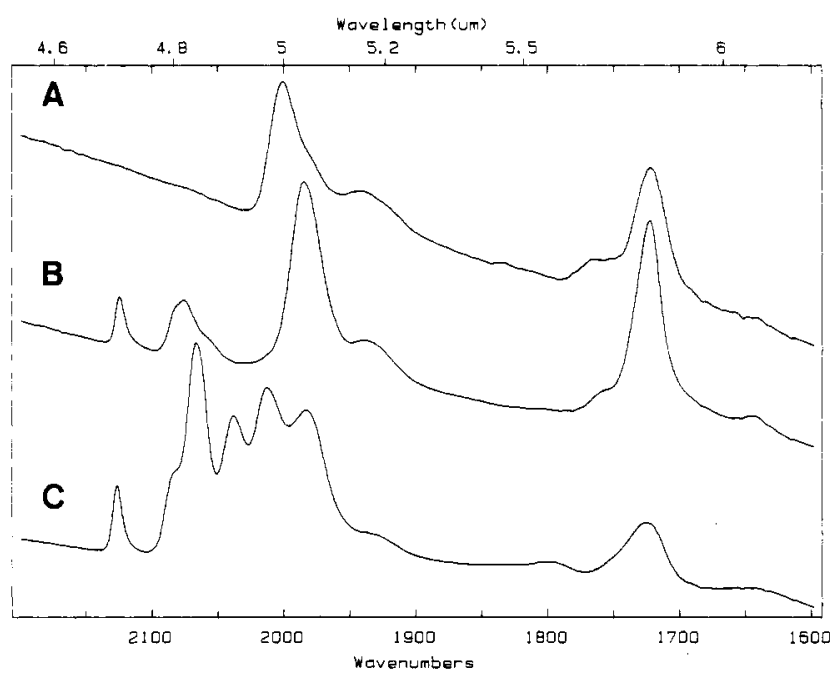

Figure 1. FTIR spectra of (a) $\left[\mathrm{CpFe}(\mathrm{CO})_{2}\right]_{2}$ adsorbed into $\mathrm{NaY}$, (b) adsorbed into $\mathrm{H} 2 \mathrm{Y}$, (c) adsorbed into $\mathrm{H} 6 \mathrm{Y}$, all at $295 \mathrm{~K}$.

spline function. Normalization to an $\mathrm{Fe}$ atom basis was based on the step height of the absorption edge. References and samples were processed similarly to avoid artifacts.

\section{Results}

Adsorption of $\left[\mathrm{CpFe}(\mathrm{CO})_{2}\right]_{2}$ into Zeolite Supports at Room Temperature. The IR CO stretching spectra of the complex $\left[\mathrm{CpFe}(\mathrm{CO})_{2}\right]_{2}$ (1) adsorbed into different zeolite supports are shown in Figure la-c. Upon loading 1 into dehydrated $\mathrm{NaY}$, the two strongest peaks of the precursor iron dimer shift to higher and lower frequencies $\left(1964,1797 \mathrm{~cm}^{-1}\right.$ in heptane $\mathrm{e}^{14} \rightarrow 1997,1725$ $\mathrm{cm}^{-1}$, Figure 1a), possibly due to interactions with the zeolite pore system. Two additional bands at 2120 and $2075 \mathrm{~cm}^{-1}$ are observed in the partially proton-exchanged sample H2YFp2 (Figure 1b). These high stretching frequencies are characteristic for the monomeric cationic carbonyl complex $\left[\mathrm{CpFe}(\mathrm{CO})_{3}\right]^{+}$(2) (reported: 2120 and $2070 \mathrm{~cm}^{-115}$ ).

Both complexes $\mathbf{1}$ and $\mathbf{2}$ are also present in the highly acidic zeolite $\mathrm{H} 6 \mathrm{Y}$, but the relative amount of the precursor 1 is strongly reduced (Figure 1c). An additional set of $\mathrm{CO}$ stretching frequencies at 2066,2039 , and $2012 \mathrm{~cm}^{-1}$ is assigned to the protonated dimer complex $\left[\mathrm{CpFe}(\mathrm{CO})_{2}\right]_{2} \mathrm{H}^{+}(3)$ (reported 2068, 2045, and $\left.2008 \mathrm{~cm}^{-116}\right)$. This assignment is based upon the corresponding solution chemistry and the selective removal of this set of bands upon thermal decomposition (see below). This complex is the major reaction product in the zeolite support with the highest proton concentration.

The formation of the protonated dimer 3 or the cationic complex 2 consumes a certain fraction of the zeolitic framework hydroxyls. The dehydrated zeolite support H6Y shows two strong hydroxyl bands resulting from protons attached to oxo bridges in the large supercage $\left(3650 \mathrm{~cm}^{-1}\right)$ and in sodalite units $\left(3550 \mathrm{~cm}^{-1}\right.$, Figure

(14) Manning, A. R. J. Chem. Soc. A 1968, 1319.

(15) Davison, A.; Green, M. L. H.; Wilkinson, G. J. Chem. Soc. London 1961, 3172.

(16) Legzdins, P.; Martin, D. T.; Nurse, C. R.; Wassink, B. Organometallics 1983, 2, 1238 . 


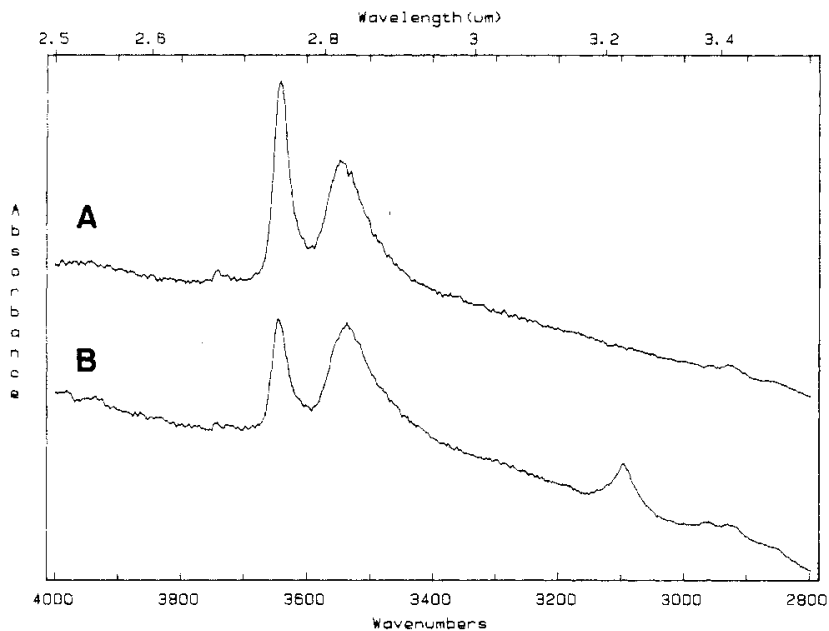

Figure 2. Consumption of zeolite hydroxyl groups upon loading with complex $\left[\mathrm{CpFe}(\mathrm{CO})_{2}\right]_{2}$ : (a) proton-exchanged zeolite $\mathrm{H} 6 \mathrm{Y}$, (b) $\mathrm{H} 6 \mathrm{Y}$ after adsorption of $\left[\mathrm{CpFe}(\mathrm{CO})_{2}\right]_{2}$ at $295 \mathrm{~K}$.
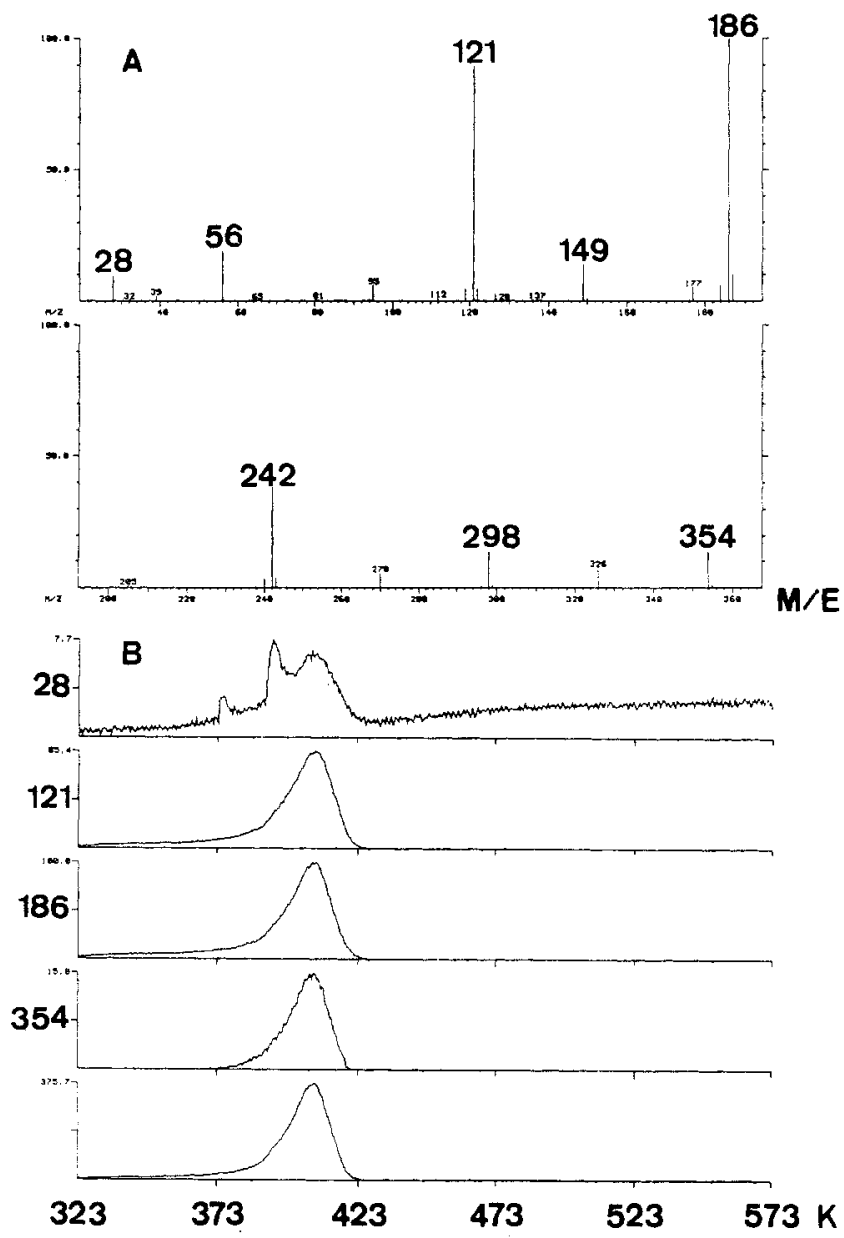

Figure 3. Mass spectra of the pyrolysis of solid $\left[\mathrm{CpFe}(\mathrm{CO})_{2}\right]_{2}$ under vacuum: (a) mass spectrum of desorbed masses up to $m / e 368$, integrated over the temperature range $380-430 \mathrm{~K}$; (b) temperature scan of the sum over all masses and of individual masses $m / e 354,186,121$, and 28 (heating rate $16 \mathrm{~K} / \mathrm{min}$ ).

2a). Upon absorption of 1 , the high-energy hydroxyl band at $3650 \mathrm{~cm}^{-1}$ decreases significantly (Figure $2 \mathrm{~b}$ ). This indicates that the complex reacts preferentially in the supercages and that it has no access to the smaller sodalite units.

Thermal Decomposition of Solid $\left[\mathrm{CpFe}(\mathrm{CO})_{2}\right]_{2}$ and Its Adduct with $\mathrm{NaY}$. Thermal treatments of the samples were performed to explore the stability and decomposition reactions of the different intrazeolite complexes. The increasing acidic strength of different zeolite supports does not only change the reaction path of the dimer 1 at room temperature but also influences its stability at elevated

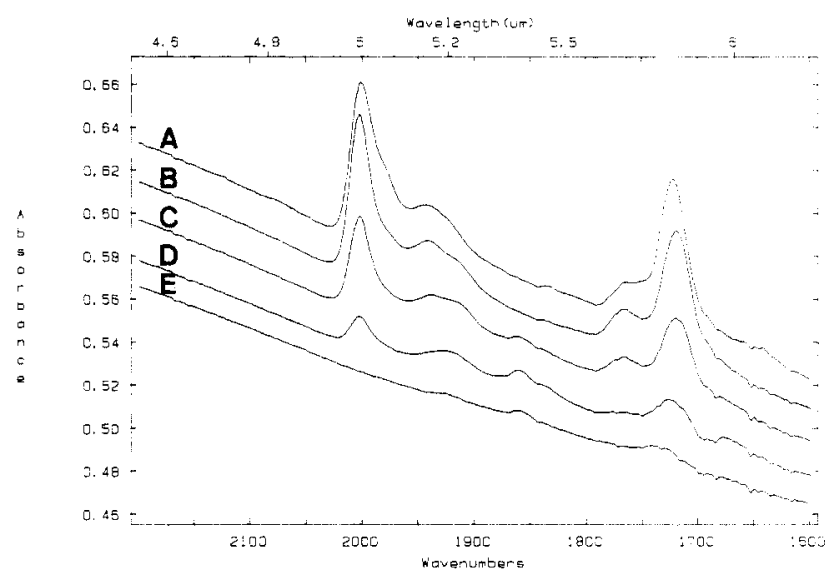

Figure 4. FTIR spectra of NaYFp2 treated at different temperatures: (a) room temperature, (b) $365 \mathrm{~K}$, (c) $378 \mathrm{~K}$, (d) $385 \mathrm{~K}$, (e) $413 \mathrm{~K}$.
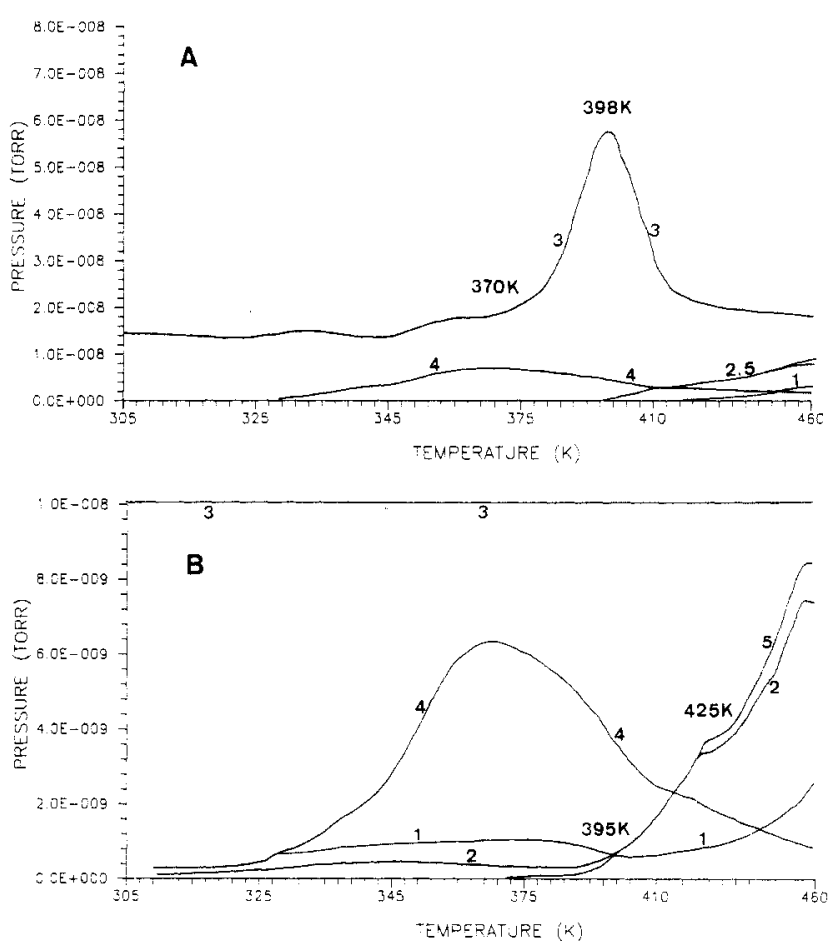

Figure 5. TPD-MS spectra of NaYFp2 corresponding to the FTIR experiments in Figure 4: (1) $m / e 18\left(\mathrm{H}_{2} \mathrm{O}^{+}\right)$, (2) $\mathrm{m} / \mathrm{e} 56\left(\mathrm{Fe}^{+}\right)$, (3) $\mathrm{m} / \mathrm{e}$ $28\left(\mathrm{CO}^{+} / \mathrm{N}_{2}{ }^{+}\right)$, (4) $m / e 41\left(\mathrm{C}_{3} \mathrm{H}_{5}{ }^{+}\right.$, hexane fragment), (5) $\mathrm{m} / e 121$ $\left(\mathrm{CpFe}^{+}\right)$; (a) full scale $=8 \times 10^{-8}$; (b) full scale $=1 \times 10^{-8}$ Torr.

temperatures. The pure compound 1 was pyrolyzed to study its decomposition without the interference of any support. Applying a fast heating program $(16 \mathrm{~K} / \mathrm{min})$ and mass-spectrometric monitoring, decomposition of 1 was observed to peak at $410 \mathrm{~K}$, with ferrocene $\left(m / e\right.$ 186), $\mathrm{FeCp}(m / e 121), \mathrm{Fe}_{2} \mathrm{Cp}_{2}(m / e$ 242), and iron $(m / e 56)$ as important fragments. Some additional liberation of $\mathrm{CO}$ occurred at 373 and $390 \mathrm{~K}$. The mass spectra accumulated over the temperature range between 380 and 430 $\mathrm{K}$ are shown in Figure 3a. Temperature scans of masses 28, 121 , 186,354 and their sum are shown in Figure $3 b$. No masses higher than $m / e 354$ were detected. A tetrameric iron cluster $\left(\mathrm{C}_{5^{-}}\right.$ $\left.\mathrm{H}_{5}\right)_{4} \mathrm{Fe}_{4}(\mathrm{CO})_{4}(m / e$ 596) which was proposed to be a decomposition intermediate by Braunstein et al. ${ }^{17}$ was not observed, nor any other possible $\mathrm{Fe}_{4} \mathrm{~L}_{x}$ species. The thermal decomposition of 1 appears to be dominated by the formation of ferrocene.

If the precursor dimer 1 is adsorbed in $\mathrm{NaY}$ zeolite (sample NaYFp2), the thermal decomposition is very similar to that of the unsupported complex (see Figure 4 for IR data). A slow

(17) Braunstein, P.; Dehand, J.; Gross, M.; Lemoine, P. J. Thermal Anal. $1975,8,109$ 


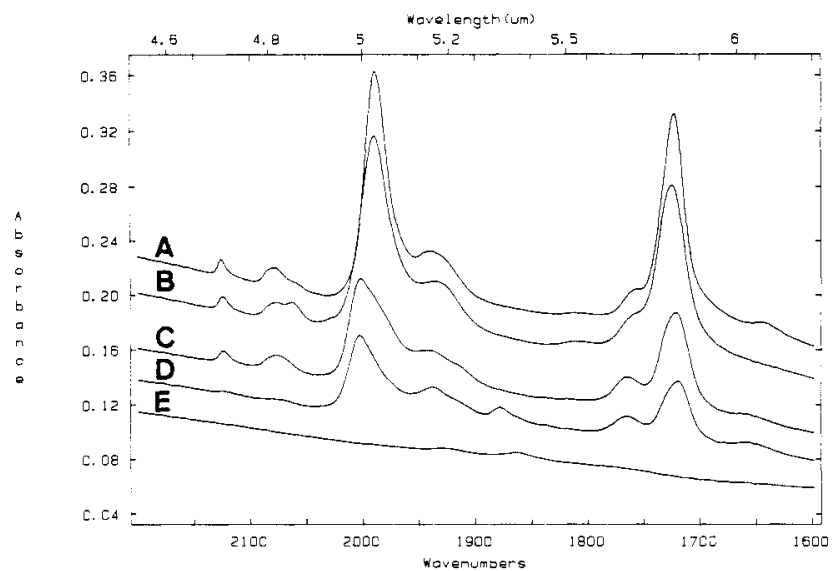

Figure 6. FTIR spectra of $\mathrm{H} 2 \mathrm{YFp} 2$ treated at different temperatures: (a) room temperature, (b) $355 \mathrm{~K}$, (c) $378 \mathrm{~K}$, (d) $400 \mathrm{~K}$, (e) $440 \mathrm{~K}$.

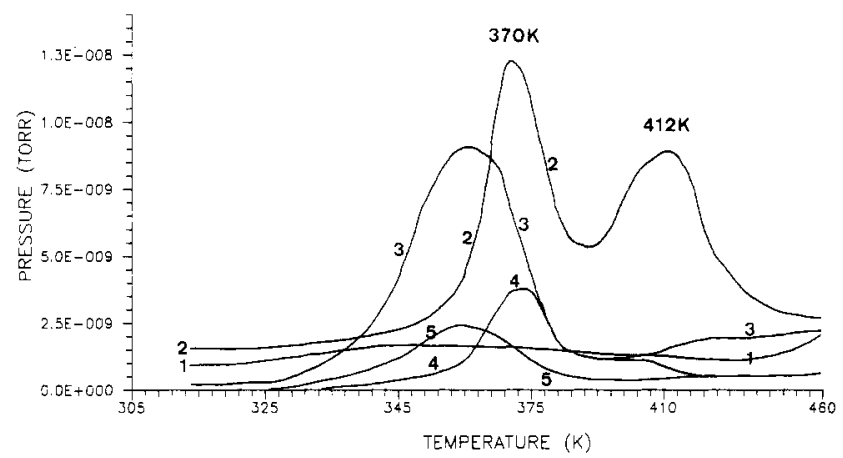

Figure 7. TPD-MS spectra of $\mathrm{H} 2 \mathrm{YFp} 2$ corresponding to the FTIR experiments in Figure 6: (1) $\mathrm{m} / \mathrm{e} 18\left(\mathrm{H}_{2} \mathrm{O}^{+}\right)$, (2) m/e $28\left(\mathrm{CO}^{+} / \mathrm{N}_{2}{ }^{+}\right)$, (3) $\mathrm{m} / \mathrm{e} 42\left(\mathrm{C}_{3} \mathrm{H}_{6}^{+}\right)$, (4) $\mathrm{m} / \mathrm{e} 66\left(\mathrm{C}_{5} \mathrm{H}_{6}^{+}\right),(5) \mathrm{m} / \mathrm{e} 72\left(\mathrm{C}_{5} \mathrm{H}_{12}{ }^{+}\right)$.

decrease of the carbonyl bands starting at $365 \mathrm{~K}$ is evident in the IR. All carbonyl ligands are split off at $413 \mathrm{~K}$. This correlates to a strong $\mathrm{CO}$ peak detected in the corresponding mass spectra with a maximum at $398 \mathrm{~K}$ (Figure 5a). No other components except residual hexane from the sample preparation are detected in the gas phase in this temperature range. Ferrocene as the most likely other decomposition product is diffusionally hindered in the zeolite cavities and starts to evolve above $395 \mathrm{~K}$, detected in the MS as iron ions $(m / e 56)$ together with protonated cyclopentadiene (not shown) and $\mathrm{FeCp}^{+}(m / e$ 121) (see Figure 5b for the mass scans).

Thermal Decomposition of $\left[\mathrm{CpFe}(\mathrm{CO})_{2}\right]_{2}$ in $\mathrm{H} 2 \mathrm{Y}$ Studied by $I R, M S$, and $E X A F S$. If the zeolite support contains a limited concentration of bridged hydroxyls (sample H2YFp2), the FTIR-TPD experiments indicate an earlier onset of the decomposition of 1 as compared to the $\mathrm{NaY}$ host. FTIR spectra of the carbonyl region at representative temperatures are shown in Figure 6. The cationic complex 2 is found to be stable up to ca. 385 K. Figure 7 shows the corresponding mass spectra. A large fraction of carbon monoxide now evolves at $370 \mathrm{~K}$ (compared to $398 \mathrm{~K}$ in $\mathrm{NaY}$ ) from the proton promoted decomposition of the dimer. This first $\mathrm{CO}$ evolution is accompanied by protonated $\mathrm{Cp}$ $(m / e 66)$, but neither the ferrocene fragment $\mathrm{FeCp}^{+}(m / e$ 121) nor $\mathrm{Fe}^{+}$is detected at higher temperatures (as found with sample NaYFp2). This indicates a different thermal decomposition path which leaves the remaining iron species trapped in the zeolite cages. A second $\mathrm{CO}$ evolution at $412 \mathrm{~K}$ corresponds to the loss of all remaining carbonyls as observed in the IR. This evolution is assigned to the thermal decomposition of the dimer similar to sample $\mathrm{NaYFp} 2$.

EXAFS spectroscopy is sensitive to the local structural environment of the X-ray absorbing atoms. It provides direct information about the first coordination spheres around the iron atoms and can help to distinguish between possible reaction products. EXAFS data were obtained from sample H2YFp2 treated under slightly different conditions from the IR experiments:
TABLE III: Bond Distances $R$, Coordination Numbers $\boldsymbol{N}$, and Debye Waller Deviations $\sigma^{2}$ of Iron Complexes in Zeolite Y Derived from EXAFS Data $^{a}$

\begin{tabular}{|c|c|c|c|c|}
\hline \multirow{3}{*}{$\frac{\text { sample }}{\left[\mathrm{CpFe}(\mathrm{CO})_{2}\right]_{2}}$} & atom pair & $R / \AA$ & $\sigma^{2} / \AA^{2}$ & $N$ \\
\hline & $\mathrm{Fe}-\mathrm{C} \mathrm{O}$ & $\begin{array}{c}1.75(1.748 \text { terminal })^{b} \\
(1.918 \text { bridged })\end{array}$ & 0.001 & $2.5(3)^{b}$ \\
\hline & $\begin{array}{l}\mathrm{Fe}-\mathrm{Cp} \\
\mathrm{Fe}-\mathrm{Fe} \\
\mathrm{Fe}-\mathrm{CQ}\end{array}$ & $\begin{array}{l}2.12(2.106)^{b} \\
2.56(2.534)^{b} \\
2.91(2.915)^{b}\end{array}$ & $\begin{array}{c}0.003 \\
-0.001 \\
0.0009\end{array}$ & $\begin{array}{l}5.0(5)^{b} \\
1.1(1)^{b} \\
1.2(3)^{b, d}\end{array}$ \\
\hline H2YFp2, $295 \mathrm{~K}$ & $\begin{array}{l}\mathrm{Fe}-\mathrm{O}^{-} \\
\mathrm{Fe}-\mathrm{CO}\end{array}$ & $\begin{array}{l}2.06 \\
1.83(1.816)^{c}\end{array}$ & $\begin{array}{r}-0.0045 \\
0.0009\end{array}$ & $\begin{array}{l}0.6 \\
1.8(3)^{c}\end{array}$ \\
\hline & $\begin{array}{l}\mathrm{Fe}-\mathrm{Cp} \\
\mathrm{Fe}-\mathrm{Fe} \\
\mathrm{Fe}-\mathrm{CO}\end{array}$ & $\begin{array}{l}2.10(2.069)^{c} \\
2.56 \\
2.90(2.928)^{c}\end{array}$ & $\begin{array}{c}-0.0005 \\
-0.003 \\
0.003\end{array}$ & $\begin{array}{l}5.3(5)^{c} \\
0.2 \\
3.9(3)^{c}\end{array}$ \\
\hline H2YFp2, $473 \mathrm{~K}$ & $\begin{array}{l}\mathrm{Fe}-\mathrm{Cp} \\
\mathrm{Fe}-\mathrm{OZ} \\
\mathrm{Fe}-\mathrm{OZ}\end{array}$ & $\begin{array}{l}2.07 \\
2.16 \\
1.93\end{array}$ & $\begin{array}{l}-0.004 \\
-0.0009 \\
-0.004\end{array}$ & $\begin{array}{l}5.4 \\
1.9 \\
0.8\end{array}$ \\
\hline $\begin{array}{l}\mathrm{H} 2 \mathrm{YFeCp} 2, \\
\quad 473 \mathrm{~K} \\
\mathrm{Fe}-\mathrm{Y} \mathrm{H}, 723 \mathrm{~K}\end{array}$ & $\begin{array}{l}\mathrm{Fe}-\mathrm{Cp} \\
\mathrm{Fe}-\mathrm{OZ} \\
\mathrm{Fe}-\mathrm{OZ} \\
\mathrm{Fe}-\mathrm{OZ}\end{array}$ & $\begin{array}{l}2.01 \\
2.07 \\
2.12 \\
1.97\end{array}$ & $\begin{array}{l}0.0007 \\
-0.001 \\
-0.006 \\
-0.004\end{array}$ & $\begin{array}{l}6.4 \\
2.1 \\
0.9 \\
1.5\end{array}$ \\
\hline
\end{tabular}

accuracy of $N \pm 20-30 \%$, of $R \pm 1-2 \%$ (for each backscattering shell). ${ }^{b}$ In parentheses: crystal structure data for complex 1 . ' In parentheses: crystal structure data for $\mathrm{CpFe}(\mathrm{CO})_{3} \mathrm{PF}_{3}$. ${ }^{d}$ The $\mathrm{CO}$ ligand was fitted with a linear $\mathrm{Fe}-\mathrm{CO}$ reference, expected to result in a smaller value for 1 , where two bridged CO ligands are present in addition to only one linear terminal $\mathrm{CO}$.

The sample was heated under vacuum up to 373 and $473 \mathrm{~K}$ and kept at these temperatures for $10 \mathrm{~h}$ each. After a period of 2 weeks when EXAFS data were taken, this sample contained primarily the cation 2 (see below). The normalized EXAFS data and Fourier transformations (FT) of the pure complex 1 and loaded into the zeolite followed by different heat treatments are shown in Figure 8. All FT's are uncorrected for phase shifts, and peak maxima appear $0.3-0.5 \AA$ shifted to lower bond distances. The FT of the precursor dimer serves as a standard to estimate relative changes between the samples. However, the dimer cannot be used for reference purposes in the EXAFS data analysis since all neighboring shells are strongly convoluted in the FT. Other standards had to be chosen for each different scatterer contribution in these samples: $\mathrm{Fe}$ foil for $\mathrm{Fe}-\mathrm{Fe}$ scatterer, $\mathrm{FeCp}_{2}$ for $\mathrm{Fe}-\mathrm{C}$, $\mathrm{FeC}_{3} \mathrm{H}_{5}(\mathrm{CO})_{3} \mathrm{Cl}$ for $\mathrm{Fe}-\mathrm{CO}$, and $\mathrm{Fe}$ (III) acac for $\mathrm{Fe}-\mathrm{O}$ scatterer. EXAFS data of these compounds are shown in Figure 9. To assure the validity of the fitting procedures described subsequently, all references were first applied to the dimer itself, and fit results were compared with the known crystal structure. A good agreement with structural data could be achieved despite the presence of multiple shells in the EXAFS data (see Figure 10a,b and Table III).

A comparison of the FT of the precursor complex 1 with that of sample H2YFp2 at room temperature (H2YFp2/295; Figure 8d) reveals dramatic changes: the peak at about $2.2 \AA$ which is assigned to the $\mathrm{Fe}-\mathrm{Fe}$ contribution from the analysis of the dimer is now dramatically reduced, while both adjacent peaks increased slightly in intensity. In a first step of the EXAFS data analysis of this sample, small inverse FT windows were applied in order to obtain EXAFS modulations consisting of single neighbor shells. This procedure reduces the number of variables in the fit procedure. The first peak at about $1.7 \AA$ (uncorrected), presumably due to the Fe-C shell from FeCp and/or FeCO contributions, was backfiltered over a range between 1.28-2.0 $\AA$. An acceptable fit of this contribution could only be achieved with two different $\mathrm{Fe}-\mathrm{C}$ bond distances of 2.10 and $1.83 \AA$ with ferrocene as $\mathrm{Fe}-\mathrm{C}$ reference. However, the quality of the fit improved if an $\mathrm{Fe}-\mathrm{O}$ shell was also considered to be present. Back-transformation of the $\mathrm{Fe}-\mathrm{Fe}$ scatterer (the second peak) would have required a very narrow window which could result in truncation errors. Therefore, a larger window of $1.28-2.30 \AA$ including the first and the second peak was applied in a second step. In addition to the previously obtained values for the $\mathrm{Fe}-\mathrm{C}$ and $\mathrm{Fe}-\mathrm{O}$ contributions, an $\mathrm{Fe}-\mathrm{Fe}$ scatterer was included in the fit of this region. In a third step, the area between 2.3 and $3.0 \AA$, corresponding to the carbonyl 



Figure 8. Normalized EXAFS data and corresponding FT $\left(k^{3}, 3-16 \AA^{-1}\right)$ of $(a, b)\left[\mathrm{CpFe}(\mathrm{CO})_{2}\right]_{2},(c, d) \mathrm{H} 2 \mathrm{YFp} 2$ at room temperature, (e, f) H2YFp2 at $373 \mathrm{~K},(\mathrm{~g}, \mathrm{~h}) \mathrm{H} 2 \mathrm{YFp} 2$ at $473 \mathrm{~K}$.

contribution in the sample, was fitted first alone and then together with the $\mathrm{Fe}-\mathrm{Fe}$ contribution over the range 2.0-3.0 $\AA$. Finally, all obtained results were combined in a three-shell fit over the entire data range between 1.2 and $3.0 \AA$. Minor adjustments to the values from the single-shell fits resulted in the calculated file shown in Figure 10d. The fit results are tabulated in Table III and can be compared to the structural data of the dimer 1 and the cationic monomer 2 . In agreement with IR data of this 

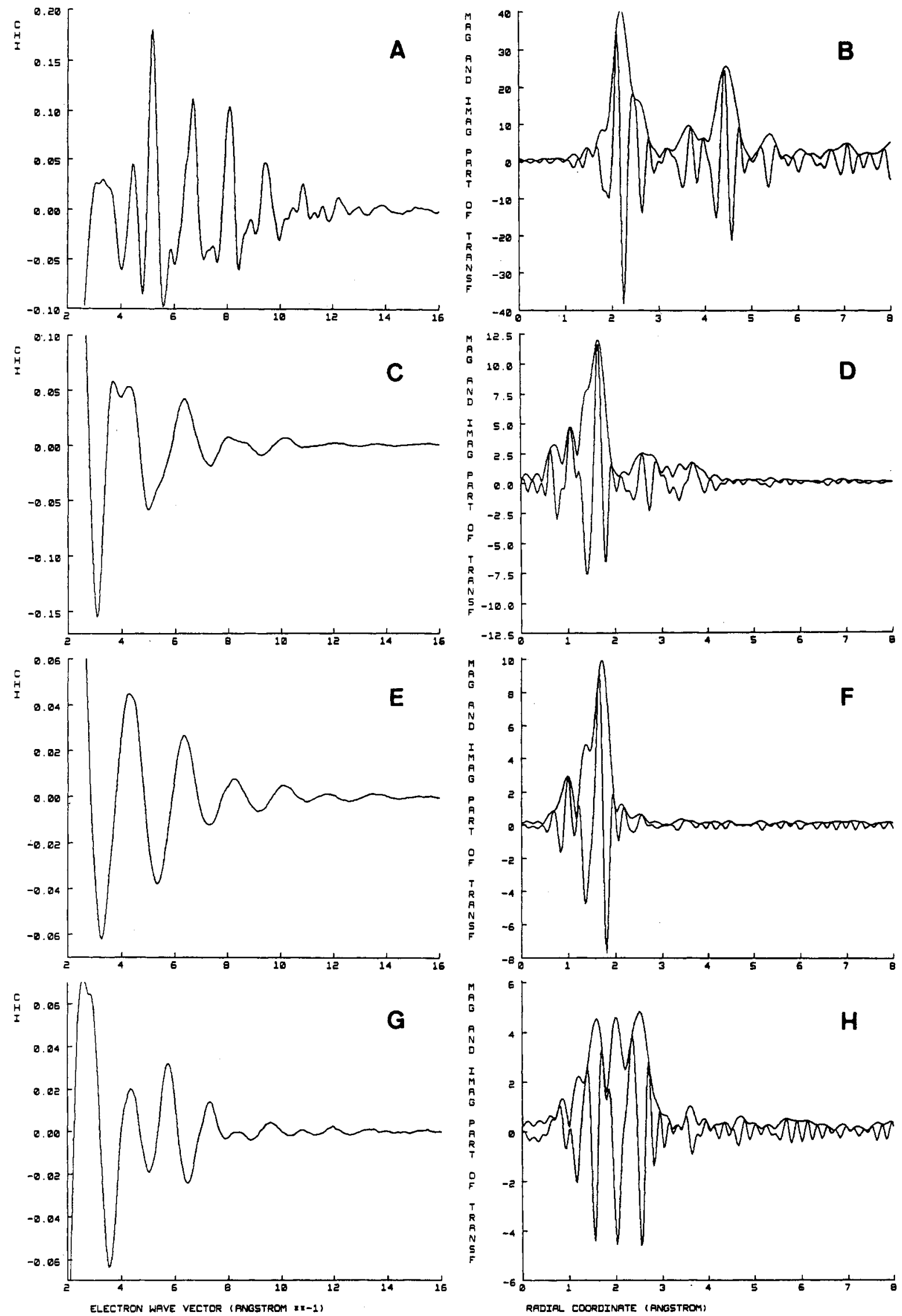

Figure 9. Normalized EXAFS data and corresponding FT $\left(k^{3}, 3-16 \AA^{-1}\right)$ of reference samples (a, b) $\mathrm{Fe}$ foil, (c, d) $\mathrm{Fe}(\mathrm{III}) \mathrm{acac},(\mathrm{e}, \mathrm{f}) \mathrm{FeCp},(\mathrm{g}, \mathrm{h})$ $\mathrm{C}_{3} \mathrm{H}_{5} \mathrm{Fe}(\mathrm{CO})_{3} \mathrm{Cl}$.

particular sample (see Figure 11), these combined EXAFS results indicate the dominant presence of the cationic monomer 2 , in addition to about $20 \%$ of unreacted dimer 1 (see below for comments on the stability of the adduct). In addition, a first-shell oxygen ligation of part of the iron phase appears to be present at $\mathrm{Fe}-\mathrm{O}=2.06 \AA$.

As shown in Figure 8f, an overall reduction of all peaks takes place when the sample is heated to $373 \mathrm{~K}$, indicating a slow 

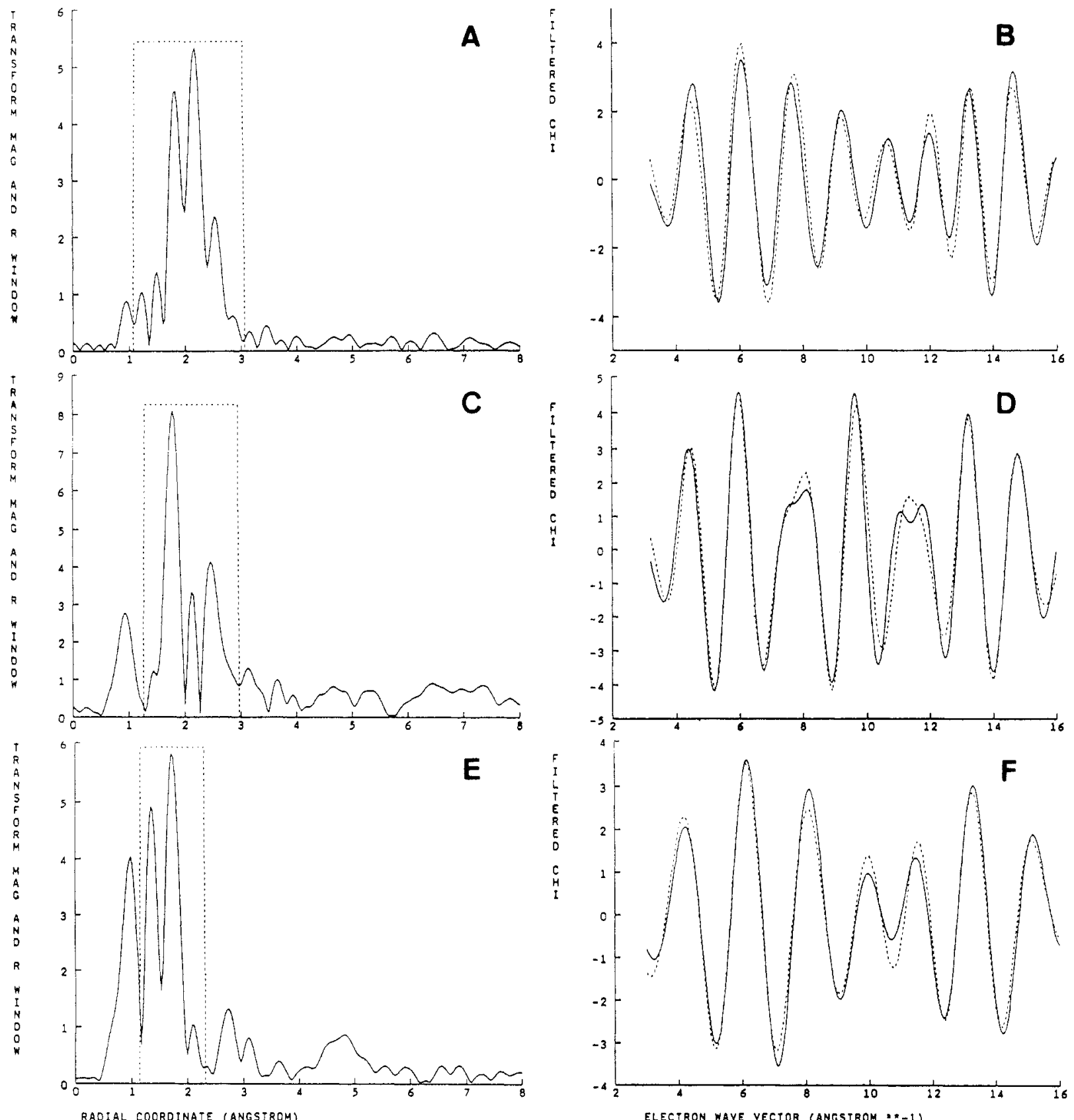

Figure 10. Magnitudes of the Fourier transformations including backtransform windows for the final fit and $k^{3}$ weighed experimental (solid line) and calculated EXAFS data (broken line) of $(a, b)$ the pure complex $\left[\mathrm{CpFe}(\mathrm{CO})_{2}\right]_{2},(\mathrm{c}, \mathrm{d})$ adsorbed into $\mathrm{H} 2 \mathrm{Y}$ at room temperature, (e, f) heated in $\mathrm{H} 2 \mathrm{Y}$ at $473 \mathrm{~K}$.

decomposition process of all fragments. A temperature treatment for $10 \mathrm{~h}$ at $473 \mathrm{~K}$ results in a total loss of carbonyl ligands, as evident from the disappearance of the EXAFS FT peak at about $2.5 \AA$ (H2YFp2/473; Figure 8h). Furthermore, the $\mathrm{Fe}-\mathrm{Fe}$ contribution is reduced to noise level. Two new features can be observed: a peak at a short distance of about $1.4 \AA$ and a small outer-shell contribution at $2.8 \AA$ (uncorrected). The latter contribution is typical for an interaction between transition-metal ions in zeolite four-ring or six-ring cation positions and the zeolite framework Si/Al atoms. ${ }^{18}$ If bare iron ions were coordinated to those sites formed by two or three oxygen atoms, the first coordination sphere would consist exclusively of zeolite oxygen atoms. However, a fit of this sample with only oxygen shells including both relevant peaks between 1.17 and $2.3 \AA$ was never satisfying even when allowing three different $\mathrm{Fe}-\mathrm{O}$ distances to be present. Inspection of the imaginary part of sample

(18) (a) Woolery, G.; Kuehl, G.; Chester, A.; Bein, T.; Stucky, G. D. Sayers, D. E. J. Phys. 1986, 47, C8-281. (b) Morrison, T. I.; Iton, L. E Shenoy, G. K.; Stucky, G. D.; Suib, S. L. J. Chem. Phys. 1981, 75, 4086.
H2YFp2/473 (Figure $8 \mathrm{~h}$ ) shows a close resemblance of the main peak at about $1.8 \AA$ with ferrocene (Figure $9 f$ ). Furthermore, this peak position remains almost unchanged compared to sample H2YFp2/295. In sample H2YFp2/295, this peak is primarily due to Fe-carbon backscattering from the cyclopentadienyl ligands. Thus a $\mathrm{Cp}$ contribution was included in the fit of $\mathrm{H} 2 \mathrm{YFp} 2 / 473$, and a good agreement between original and calculated file was achieved as shown in Figure 10f. The results listed in Table III indicate the presence of $\mathrm{Fe}-\mathrm{Cp}$ and $\mathrm{Fe}-\mathrm{O}$ coordination shells in this sample. The two different $\mathrm{Fe}-\mathrm{O}$ distances suggest the presence of two iron species, i.e., a zeolite anchored $\mathrm{CpFe}(\mathrm{OZ})_{n}$ "half-sandwich" fragment in addition to a smaller amount of bare iron ions at the shorter oxygen bond distance. Additional TPD-MS experiments were carried out to probe the presence of $\mathrm{CpFe}^{+}$ fragments in the zeolite. After heating for $10 \mathrm{~h}$ at $383 \mathrm{~K}$ under vacuum, the temperature was ramped up to $500 \mathrm{~K}$. The corresponding mass spectra showed indeed the evolution of protonated $\mathrm{Cp}$ long after all carbonyl ligands have been desorbed. This result provides additional evidence for the formation of intrazeolite $\mathrm{FeCp}$ fragments and their high thermal stability. 


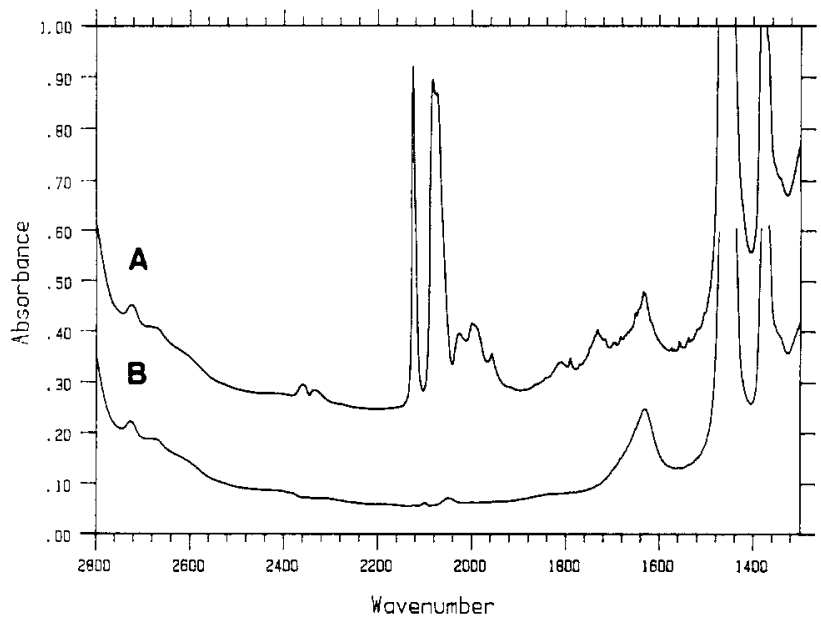

Figure 11. FTIR spectrum of $\left[\mathrm{CpFe}(\mathrm{CO})_{2}\right]_{2}$ adsorbed into $\mathrm{H} 2 \mathrm{Y}$ (nujol). Sample H2YFp2 examined in EXAFS experiments (a) at room temperature and (b) at $473 \mathrm{~K}$.

The coordination distance between bare iron ions and zeolite oxygen in this sample is very similar to that found in sample $\mathrm{FeY}$. (This sample was prepared by ion exchange with $\mathrm{FeSO}_{4}$ under anaerobic conditions, dehydrated under oxygen flow, and reduced under hydrogen at $623 \mathrm{~K}$ ). A fit shown in Figure 12b was achieved with two oxygen distances of 2.12 and $1.97 \AA$ respectively, values close to those obtained from X-ray diffraction data of similar samples. ${ }^{19}$ The corresponding average coordination numbers (Table III) indicate a 1:1 partition between sites having 3- and 2 -fold coordination to oxygen.

Thermal Decomposition of $\left[\mathrm{CpFe}(\mathrm{CO})_{2}\right]_{2}$ in H6Y (Sample $H 6 Y F p 2$ ). If the precursor dimer 1 is loaded into fully proton exchanged HY zeolite (sample H6YFp2), the major intrazeolite reaction product is the protonated dimer 3 (2066, 2039, and 2012 $\mathrm{cm}^{-1}$; reported: 2068,2045 , and $2022 \mathrm{~cm}^{-1}$ in an $\mathrm{H}_{2} \mathrm{SO}_{4}$ film ${ }^{20}$ ), in addition to some carbonyl cation 2 and unreacted 1 (Figure 13). Upon heating, the unreacted dimer is the first to decompose at even lower temperature than that observed in $\mathrm{H} 2 \mathrm{YFp} 2$ and NaYFp2. Between 333 and $353 \mathrm{~K}$, decomposition of 3 occurs prior to that of the cation, which is stable up to about $400 \mathrm{~K}$. Mass spectra taken simultaneously with the FTIR experiments are shown in Figure 14. Evolution of carbon monoxide begins at 345 $\mathrm{K}$ and develops into continuous desorption with broad peaks at 370 and $445 \mathrm{~K}$. A fragment $m / e 67$ (probably $\mathrm{C}_{5} \mathrm{H}_{7}^{+}$) shows some correlation with the $\mathrm{CO}$ evolution. It appears that the highly acidic environment of $\mathrm{H} 6 \mathrm{Y}$ causes not only fragmentation of the iron complex as observed in the FTIR studies but also acid-catalyzed reactions of the organic ligands present in the zeolite. These reactions complicate the interpretation of TPD data of highly acidic supports.

Intrazeolite Chemistry of Ferrocene. Partially acid zeolite $\mathrm{H} 2 \mathrm{Y}$ was loaded with 2 molecules of ferrocene per supercage (sample $\mathrm{H} 2 \mathrm{YFeCp}_{2}$ ). If this sample is heated under vacuum to $473 \mathrm{~K}$, analysis of the corresponding EXAFS data indicates that, despite a different precursor complex, again the "half-sandwich" fragment $\mathrm{CpFe}(\mathrm{OZ})_{n}(\mathrm{OZ}=$ zeolite oxygen, $n=2)$ has been formed (Table III). The usually very stable complex (decomposition temperature $>800 \mathrm{~K}$ ) remains almost unchanged when adsorbed into the zeolite and heated to $373 \mathrm{~K}$ (compare Figures $9 \mathrm{f}$ and $15 \mathrm{a}, \mathrm{b}$ ). However, a fraction of the ligands is lost between 373 and $473 \mathrm{~K}$ as shown in Figure $15 \mathrm{c}$ by the reduction of the peak at about $1.7 \AA$ (uncorrected). The shape of the imaginary part of the FT remains almost unchanged but grows broader. Small higher shell contributions are visible at about $2.6 \AA$ which grow with rising temperature. These features are tentatively assigned to zeolite $\mathrm{Si} / \mathrm{Al}$ atoms. A good fit is obtained if a convolution of cyclopentadienyl

(19) Pearce, J. R.; Mortier, W. J.; Uytterhoeven, J. B. J. Chem. Soc., Faraday Trans I 1981, 77, 937.

(20) Davison, A.; McFarlane, W.; Pratt, L.; Wilkinson, G. J. Chem. Soc. 1962, 3653 . and oxygen ligands is considered (see Table III, Figure 15d). Thus, the $\mathrm{CpFe}$ fragment is coordinated to the zeolite oxygens at $2.07 \AA$. The loss of cyclopentadienyl from the ferrocene-loaded sample upon heating is also confirmed in the desorption mass spectrum. Decomposition is not accompanied by the appearance of the $\mathrm{FeCp}^{+}$fragment in the mass spectrum $(m / e$ 121) which is observed in the MS of ferrocene. Thus, ferrocene is not desorbed as an intact molecule, but fragments such as $\mathrm{FeCp}^{+}$must be retained in the zeolite host. In conclusion, the thermal decomposition of ferrocene in partially acid zeolite $Y$ results in the formation of zeolite-attached half-sandwich fragments. After being heated at $473 \mathrm{~K}$, both samples $\mathrm{H} 2 \mathrm{YFp} 2$ and $\mathrm{H} 2 \mathrm{YFeCp} 2$ exhibit a bright green color. In contrast, the samples differ markedly in color if only heated to $373 \mathrm{~K}$ (H2YFp2; pink; and $\mathrm{H} 2 \mathrm{YFeCp} 2$, grey brown). This supports the formation of similar intrazeolite ligand spheres even though the iron precursor complexes were different.

Homogeneity of Iron Deposition in the Zeolite Host. An important issue is the question whether the iron species are homogeneously distributed throughout the zeolite microcrystals or if they are preferentially deposited on the crystal surfaces. Model calculations based upon average zeolite crystal sizes of $2 \mu \mathrm{m}$ show that the outer crystal surface area is about 2 orders of magnitude smaller than required to accommodate the loaded amount of iron species at zeolite coordination sites. Together with this result, the complete intrazeolite uptake of the iron complexes in this study (and of other organometallics in previous studies ${ }^{6,9}$ ) provides strong evidence for predominant intrazeolite deposition of the iron species.

Adsorption of $\mathrm{CO}$ into Iron-Loaded Zeolite Samples. Carbon monoxide (20 Torr) was equilibrated with samples at different stages of the intrazeolite reactions to examine the reactivity of the remaining fragments in the zeolite host. Only gaseous $\mathrm{CO}$ and some carbon dioxide were detected in the IR data of samples which have the cationic complex 2 still present (sample H6YFp2 at $365 \mathrm{~K}$ ), or when finally all CO ligands are split off (H2YFp2 at $460 \mathrm{~K}$ ). No new carbonyl complexes are formed and all $\mathrm{CO}$ is removable upon evacuation. This is not surprising in light of the saturated and stable coordination spheres of the proposed reaction products. The formation of $\mathrm{CO}_{2}$ is probably due to a catalytic conversion of $\mathrm{CO}$.

\section{Discussion and Summary}

Intrazeolite Reactions at Room Temperature. The cleavage reaction of 1 is well studied in homogeneous medium. ${ }^{21-25}$ The dimer 1 reacts in $\mathrm{HCl} / \mathrm{CHCl}_{3}$ to $\mathrm{CpFe}(\mathrm{CO})_{2} \mathrm{Cl}$, which forms the tricarbonyl cation 2 under $\mathrm{CO}$ pressure. ${ }^{15}$ Proton-exchanged zeolites $\left(\mathrm{p} K_{\mathrm{a}}<-3\right)$ represent solid acids of strength comparable to concentrated mineral acids. ${ }^{26}$ It is found in this study that the tricarbonyl cation 2 forms in the zeolite pores via oxidation of the precursor dimer at room temperature. The EXAFS data agree very well with this reaction path as described in the following.

The intensity of the iron-iron scatterer pair is reduced to $20 \%$ after adsorption into the zeolite, indicating cleavage of the metal-metal bonds of 1 . Coordination distances and numbers derived from the EXAFS data are in line with the formation of 2. Crystallographic data of the $\mathrm{CpFe}(\mathrm{CO})_{3} \mathrm{PF}_{6}$ salt ${ }^{27}$ show an $\mathrm{Fe}-\mathrm{C}$ bond length of all $\mathrm{CO}$ ligands of $1.82 \AA$ compared to 1.75 and $1.92 \AA$ in the dimeric complex and to $1.83 \AA$ found in the EXAFS analysis of sample H2YFp2/295. The iron-cyclopentadienyl distance is reduced from $2.12 \AA$ in the pure complex to $2.10 \AA$, close to the crystallographic value of $2.07 \AA$ in the $P_{6}$ salt. Both features combined give rise to the observed increase

(21) Giering, W. P.; Rosenblum, M. J. Chem. Soc., Chem. Commun. 1971, 441.

(22) Johnson, E. C.; Meyer, T. J.; Winterton, N. Inorg. Chem. 1971, 10 , 1673.

(23) Dombeck, B. D.; Angelici, R. J. Inorg. Chim. Acta 1973, 7, 345.

(24) Boyle, P. F.; Nicholas, K. M. J. Organomet. Chem. 1976, 114, 307.

(25) Catheline, D.; Astruc, D. J. Organomet. Chem. 1984, 266, C11.

(26) Beaumont, R.; Barthomeuf, D.; Trambouze, Y. Adv. Chem. Ser. $1971,102,327$.

(27) Gress, M. E.; Jacobson, R. A. Inorg. Chem. 1973, 12, 1746. 

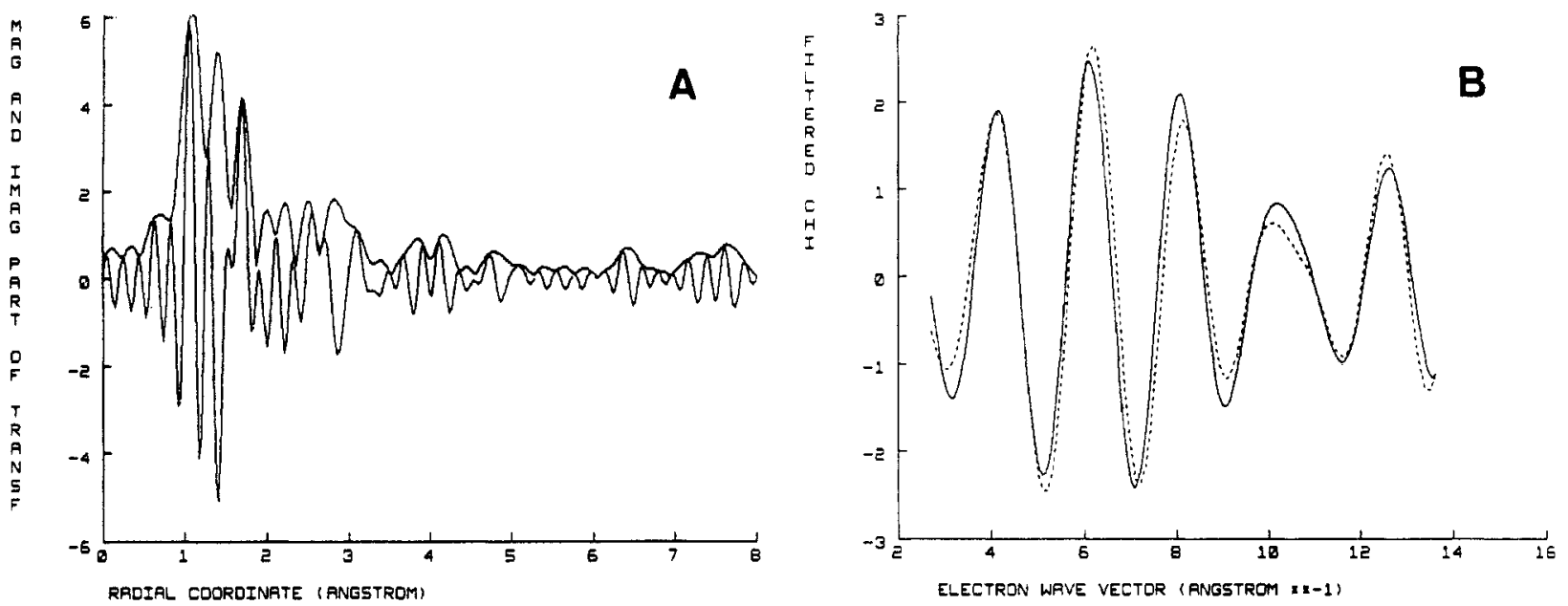

Figure 12. EXAFS spectra of FeY after reduction at $623 \mathrm{~K}$ : (a) FT ( $k^{3}$ weighed $\left.2.7-13.6 \AA^{-1}\right)$, (b) experimental data $\left(k^{3}\right.$, solid line) and calculated file (broken line).

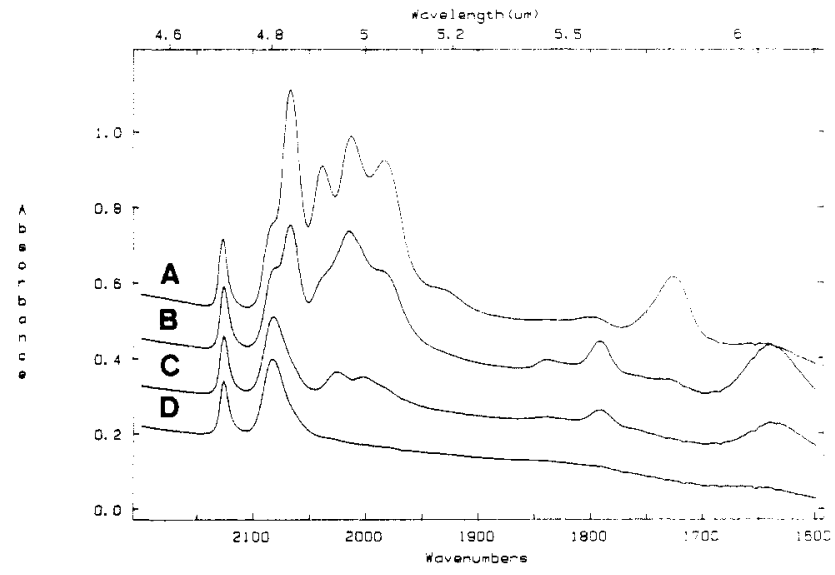

Figure 13. FTIR spectra of sample H6YFp2 at different temperatures: (a) room temperature, (b) $355 \mathrm{~K}$, (c) $370 \mathrm{~K}$, (d) $385 \mathrm{~K}$.

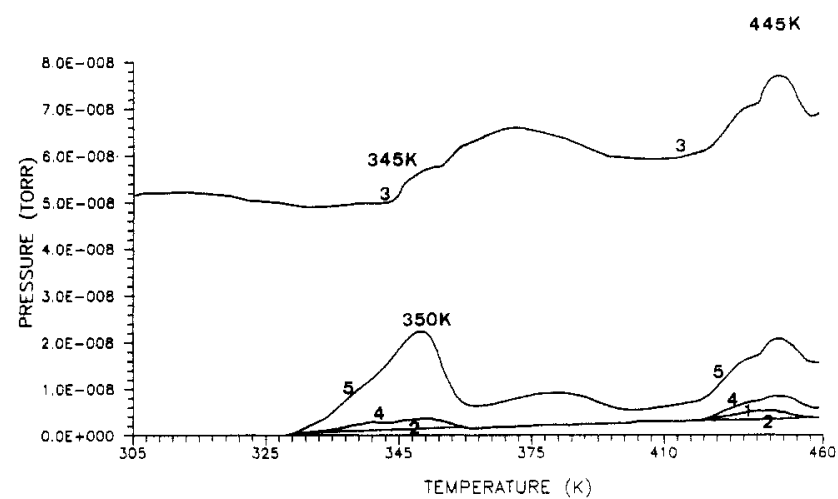

Figure 14. TPD-MS spectrum of H6YFp2 corresponding to the FTIR data of Figure 13: (1) $m / e 18\left(\mathrm{H}_{2} \mathrm{O}^{+}\right)$, (2) $m / e 55\left(\mathrm{C}_{4} \mathrm{H}_{7}^{+}\right)$, (3) $m / e$ $28\left(\mathrm{CO}^{+} / \mathrm{N}_{2}{ }^{+}\right)$, (4) $\mathrm{m} / \mathrm{e} 41\left(\mathrm{C}_{3} \mathrm{H}_{5}^{+}\right)$, (5) m/e $67\left(\mathrm{C}_{5} \mathrm{H}_{7}{ }^{+}\right)$.

of the peak at $1.8 \AA$, due to overlap of three carbonyls with the $\mathrm{Cp}$ fragment. Additional increase in intensity of the first peak is due to iron coordination to zeolite oxygens. The bond angle between the bridged $\mathrm{Fe}-\mathrm{CO}_{b}$ in 1 is $138^{\circ}$, remarkably different from $176^{\circ}$ in the monomer. This almost linear arrangement of the $\mathrm{CO}$ ligands in sample H2YFp2/295 leads to an enhancement of the "focus effect" of the multiple scattering process, resulting in an increase in peak intensity at $2.9 \AA$. Furthermore, the increase of the third peak may be caused by overlap with the Si/Al scatterers corresponding to zeolite coordinated iron ions. Since the $\mathrm{Fe}-\mathrm{O}$ bond length in $\mathrm{H} 2 \mathrm{YFp} 2 / 295$ is so similar to that of the $\mathrm{CpFe}(\mathrm{OZ})_{n}$ fragments of the other samples, we assign this bond to similar fragments formed already at room temperature. The EXAFS data are consistent with the formation of about $40 \% 2$,

$40 \% \mathrm{CpFe}(\mathrm{OZ})_{2}$, and a remainder of $20 \% 1$.

The formation of the cationic complex 2 is not only determined by the relative concentration and strength of intrazeolite acid groups present, but it is also kinetically controlled. IR spectra taken on subsequent days show a growth of the cation content at the expense of the original dimer 1 . Controlled adsorption of water or oxygen did not affect this reaction. This shows that it is not caused by potential contamination with these species. The slow increase of 2 explains why in the EXAFS sample measured about 2 weeks after synthesis $80 \%$ of the dimer is cleaved into the cationic complex, compared to only $20 \%$ in the sample shown in Figure 7. IR data of the EXAFS sample indicate indeed a much larger fraction of complex 2 (Figure 11).

In conclusion, it is demonstrated that the consumption of the original complex $\left[\mathrm{CpFe}(\mathrm{CO})_{2}\right]_{2}$ is very dependent upon the concentration of acid hydroxyls offered by the solid reaction medium. It can be summarized in the following outline.

Important reaction products with increasing relative amount of protons:
$\mathrm{NaY}$
$\mathrm{H} 2$ YFp2
$\left[\mathrm{CpFe}(\mathrm{CO})_{2}\right]_{2}$
H6YFp2
$\mathrm{CpFe}(\mathrm{OZ})_{n}$
$\left[\mathrm{Cp}(\mathrm{CO})_{2} \mathrm{Fe}\right]_{2} \mathrm{H}^{+}>$
$\left[\mathrm{CpFe}(\mathrm{CO})_{3}\right]^{+}$

An increasing relative amount of protons favors the oxidation of the dimer to the monomeric cation. A similar reaction in homogeneous medium was observed only with acids having a $\mathrm{p} K$ $<1$. Oxidative cleavage of the iron dimer occurred to give $\left[\mathrm{CpFe}(\mathrm{CO})_{2} \mathrm{~L}\right]$, where $\mathrm{L}$ is the acid anion or a ligating solvent molecule. ${ }^{28}$

The zeolite host $\mathrm{H} 6 \mathrm{Y}$ with even higher proton activity opens a reaction path to form the protonated dimer 3 . The analogous reaction in homogeneous medium is described in a recent publication. ${ }^{16}$ In a $\mathrm{HBF}_{4} \cdot \mathrm{OMe}_{2} / \mathrm{CH}_{2} \mathrm{Cl}_{2}$ solution, complex 1 is transformed into the hydrogen-bridged iron dimer [Cp$\left.(\mathrm{CO})_{2} \mathrm{Fe}\right]_{2} \mathrm{H}^{+}$under cleavage of the $\mathrm{Fe}-\mathrm{Fe}$ bond.

Our experimental results can be understood with the following tentative reaction pathways at room temperature:

medium acidity ( $\mathrm{H} 2 \mathrm{YFp} 2)$ :

$\left[\mathrm{CpFe}(\mathrm{CO})_{2}\right]_{2}+2 \mathrm{ZOH}+\mathrm{OZ} \rightarrow$

$$
\left[\mathrm{CpFe}(\mathrm{CO})_{3}\right]^{+} \mathrm{OZ}^{-}+\mathrm{H}_{2}+\mathrm{CO}+\mathrm{CpFe}(\mathrm{OZ})_{2}
$$

( $\mathrm{ZOH}$, zeolite bridged hydroxyls)

high excess of protons (H6YFp2):

$\left[\mathrm{CpFe}(\mathrm{CO})_{2}\right]_{2}+x \mathrm{ZOH} \rightarrow$

$$
\left\{\left[\mathrm{Cp}(\mathrm{CO})_{2} \mathrm{Fe}\right]_{2} \mathrm{H}\right\}^{+} \mathrm{OZ} Z^{-}+(x-1) \mathrm{ZOH}
$$

(28) Callan, B.; Manning, A. R. J. Organomet. Chem. 1983, 252, C81. (29) Wyckoff, R. W. G. Crystal Structures, 2nd ed.; Interscience: New York, 1963.

(30) Iball, J.; Morgan, C. H. Acta Crystallogr. 1967, 23, 239

(31) Seiler, P.; Dunitz, J. D. Acta Crystallogr. 1979, B35, 1068

(32) Simon, F. E.; Lauher, J. W. Inorg. Chem. 1980, 19, 2338 

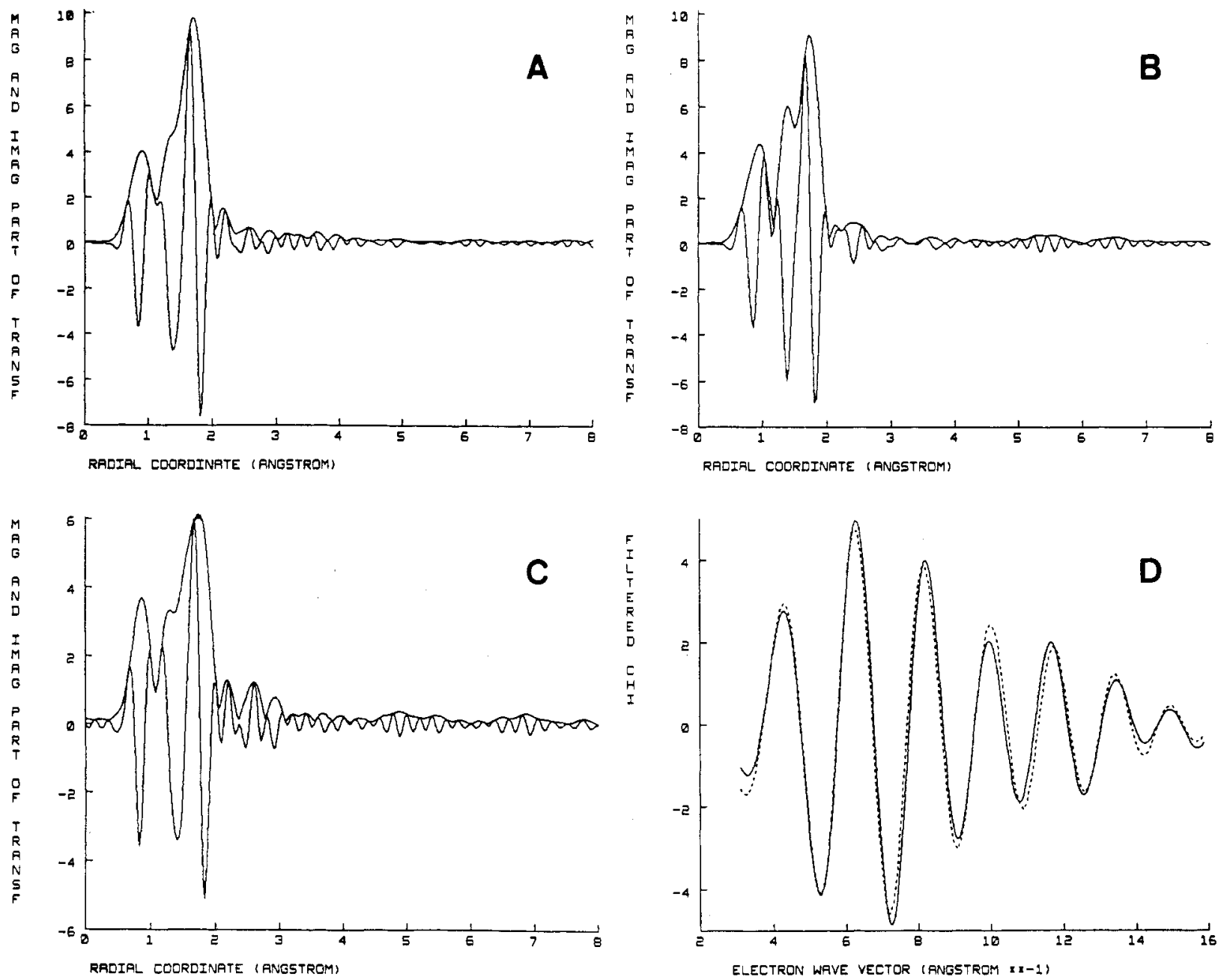

Figure 15. EXAFS FT of $\mathrm{FeCp}_{2}$ adsorbed into $\mathrm{H} 2 \mathrm{Y}$ (sample $\mathrm{H} 2 \mathrm{YFeCp}$ ) (a) at room temperature, (b) at $373 \mathrm{~K}$, (c) at $473 \mathrm{~K}$, (d) experimental data $\left(k^{3}\right.$, solid line) and calculated file (broken line) of sample c.

Intrazeolite Reactions at Elevated Temperature. Heating sample $\mathrm{H} 2 \mathrm{YFp} 2$ at $473 \mathrm{~K}$ for $10 \mathrm{~h}$ results in striking changes of the EXAFS data (Figure $8 \mathrm{~h}$ ). The small remaining $\mathrm{Fe}-\mathrm{Fe}$ backscattering contribution is reduced down to noise level, as is the contribution from linear $\mathrm{CO}$ ligands. The dominant features are two peaks near the position of the original Fe-Cp shell (Figure $8 \mathrm{f})$. The fitting routine deconvolutes these peaks, indicating an $\mathrm{Fe}-\mathrm{Cp}$ contribution at $2.07 \AA$. The $\mathrm{Fe}-\mathrm{Cp}$ distance is close to that of 2 (whereas $\mathrm{Fe}-\mathrm{Cp}$ in $\mathrm{Cp}_{2} \mathrm{Fe}$ is $2.03 \AA$ ), and suggests the presence of a $\mathrm{CpFe}-\mathrm{OZ}$ fragment. Two new $\mathrm{Fe}-\mathrm{O}$ contributions are found at $R=2.16$ and $1.93 \AA$ (Table III). These relative short bond distances are comparable to those found in an XRD study on Fe-Y zeolites dried at $673 \mathrm{~K}^{19}$ The result that an optimum fit was derived with two oxygen contributions indicates the presence of two species (bare iron ions plus $\mathrm{CpFe}(\mathrm{OZ})_{n}$ as discussed above). A smaller peak at about $2.8 \AA$ is now clearly visible at this temperature and is assigned to backscattering from the zeolite framework metals Si or Al. The combined appearance of these new peaks is a strong indication for coordination of the resulting complex fragments to zeolite cation sites. This has been demonstrated in several instances for transition-metal ions migrating into six-rings (or four-rings) upon dehydration of the respective aquo complexes residing in the zeolite host supercage. ${ }^{18}$

At higher temperatures, the tricarbonyl cation thus splits off all $\mathrm{CO}$ ligands to form the "half-sandwich" $\mathrm{CpFe}^{+}(\mathrm{OZ})_{n}{ }^{-}$, $\mathrm{co}-$ ordinated to oxygen of the oxygen rings in the zeolite supercage. The EXAFS data suggest that $n$ is between 2 and 3 , depending on the fraction of bare iron ions at $\mathrm{Fe}-\mathrm{O}=1.93 \AA$. The limited accuracy of coordination numbers and the potential presence of several sites do not allow precise determination of the partition of the CpFe fragment between four-ring (SIII) and six-ring SII sites. The combined presence of $\mathrm{Fe}^{2+}$ and $\mathrm{CpFe}(\mathrm{OZ})_{2}$ fragments and the results discussed above would be consistent with the following decomposition reactions:

$$
\begin{gathered}
{\left[\mathrm{CpFe}(\mathrm{CO})_{2}\right]_{2}+4 \mathrm{HOZ} \stackrel{470 \mathrm{~K}}{\longrightarrow} \underset{4 \mathrm{CO}_{\mathrm{g}}}{\longrightarrow}+2 \mathrm{CpH}_{\mathrm{g}}+2 \mathrm{Fe}^{2+}(\mathrm{OZ})_{2}+\mathrm{H}_{2}} \\
{\left[\mathrm{CpFe}(\mathrm{CO})_{3}\right]^{+} \mathrm{OZ}^{-}+\mathrm{OZ} \stackrel{470 \mathrm{~K}}{\longrightarrow} 3 \mathrm{CO}_{\mathrm{g}}+\mathrm{CpFe}(\mathrm{OZ})_{2}}
\end{gathered}
$$

In conclusion, this study demonstrates that depending upon the stoichiometry of zeolite protons vs the amount of iron starting complex different intrazeolite reaction routes are predominant. The EXAFS studies confirm the infrared and TPD-MS results related to carbonyl species and show that at elevated temperatures organoiron fragments are anchored to the zeolite framework after loss of carbonyl and other ligands. Related studies of other organometallics in zeolites are reported elsewhere ${ }^{33}$ and will be subject of future reports.

Acknowledgment. We appreciate the assistance of P. Enzel with some of the FTIR studies. Acknowledgment is made to the donors of the Petroleum Research Fund, administered by the American Chemical Society, and to the Sandia-University Research Program (DOE), for partial support of this research. The operational funds for NSLS beamline $\mathrm{X}-11 \mathrm{~A}$ are supported by DOE grant DE-AS0580ER 10742.

Registry No. 1, 12154-95-9; ferrocene, 102-54-5.

(33) Borvornwattananont, A.; Moller, K.; Bein, T. J. Phys. Chem., in press. 